Available online on 15.3.2018 at http://ujpr.org
Universal Journal of Pharmaceutical Research
An International Peer Reviewed Journal
Open access to Pharmaceutical research is an open access article distributed under the terms of the Creative Commons Attribution-Non
Commercial Share Alike 4.0 License which permits unrestricted non commercial use,
provided the original work is properly cited
Volume 3, Issue 1, 2018

\title{
HYPOGLYCEMIC AND LIPID LOWERING EFFECT OF AQUEOUS FRESH LEAF EXTRACT OF CHROMOLAENA ODORATA (LINN) IN ALBINO WISTAR RATS FED DIFFERENT CONCENTRATIONS OF CHOLESTEROL ENRICHED DIET
}

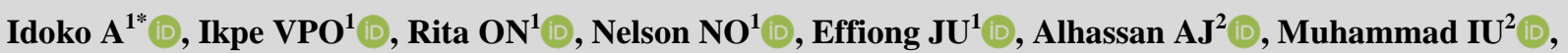 \\ Abubakar $\mathbf{N}^{3}\left(\mathrm{D}\right.$, Abubakar $\mathbf{S M}^{2}$ iD, Ugwudike PO ${ }^{1}$ \\ ${ }^{l}$ Department of Biochemistry, Faculty of Natural Sciences Caritas University Amorji - Nike, P.M.B. 01784, Enugu, Nigeria. \\ ${ }^{2}$ Department of Biochemistry, Faculty of Basic Sciences, Bayero University, P.M.B. 3011, Kano, Nigeria. \\ ${ }^{3}$ Department of Biochemistry, Faculty of Sciences, Federal University Dutse, P.M.B. 7156, Jigawa State, Nigeria.
}

\section{ABSTRACT}

Objectives: High lipids and carbohydrate have been seriously implicated to cardiovascular problems, which has led to several uses of medicinal plants for traditional remedies. The present study investigated the lipid lowering activity of fresh leaf extract of Chromolaena odorata in Albino wistar rats.

Methods: Twenty (20) rats used for the study were grouped into four groups of five (5) rats each. Group I served as normal control, group II, III and IV served as test groups, fed 75, 108 and $148 \mathrm{~g}$ of cholesterol enriched diet for one week and thereafter, administered with 50,100 and $150 \mathrm{mg} / \mathrm{kg}$ body weight of fresh leaf extract of Chromolaena odorata respectively for four (4) days. Lipid profile and blood glucose were assayed at fed state and after administration. Results showed a significant $(P<0.05)$ increase in total cholesterol, triacylglycerol, low density lipoprotein, blood glucose concentration and body weight compared with control group in fed state.

Results: Administration with fresh leaf extract of Chromolaena odorata showed a significant $(P<0.05)$ increase in high density lipoprotein, significant $(P<0.05)$ decrease in blood glucose concentration, low density lipoproteins, triacylglycerol, total cholesterol and body weight of rats. The oral treatment with 50,100 and $150 \mathrm{mg} / \mathrm{kg}$ body weight of the fresh leaf extract of this study demonstrated a general hypoglycemic and hypolipidemic activity not necessary a dose dependent pattern.

Conclusion: It may therefore be concluded that the hypoglycemic and hypolipidemic activity of Chromolaena odorata taken freshly squeezed could be due to its phytochemical and antioxidants content.

Keywords: Blood glucose concentration; cholesterol; Chromolaena odorata; hyperlipidemia; hypoglycemic; weight loss.

Article Info: Received 15 December 2017; Revised 15 February; Accepted 8 March, Available online 15 March 2018

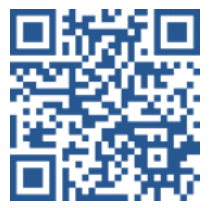

\section{Cite this article-}

Idoko A, Ikpe VPO, Rita ON, Nelson NO, Alhassan AJ, Muhammad IU, Abubakar N, Abubakar SM Ugwudike PO. Hypoglycemic and lipid lowering effect of aqueous fresh leaf extract of chromolaena odorata (linn) in albino wistar rats fed different concentrations of cholesterol enriched diet. Universal Journal of Pharmaceutical Research 2018; 3(1): 37-42.

Address for Correspondence

DOI: http://doi.org/10.22270/ujpr.v3i1.R7

Idoko A., Department of Biochemistry, Faculty of Natural Sciences Caritas University Amorji - Nike, P.M.B. 01784, Enugu, Nigeria. Telephone: +2348032354823, E-mail: idokoalexanderl @gmail.com

\section{INTRODUCTION}

Improved intensive agricultural technique, science and technology have improved life style and availability of food, resulting to unhealthy eating habit (overeating) and subsequent obesity ${ }^{1}$. It has been reported that excessive consumption of saturated fatty food poses cardiovascular health risk $^{2}$. Lipids are said to be the building blocks of fats and fatty substances found in animals and plants, composed mainly of cholesterol, triglycerides, lipoproteins and phospholipids. Lipids are insoluble in water and are stored in form of
Triacylglycerol in the body which serves as sources of energy ${ }^{3}$. Cholesterol is exclusively found in all animal cells and in animal-based foods. Although it has been tagged bad and dangerous when levels rise in blood above $200 \mathrm{mg} / \mathrm{dl}$. It is an essential nutrient necessary for many functions, which include; repairing of cell membranes, synthesis of vitamin D on the skin's surface, production of hormones (estrogen and testosterone) ${ }^{2}$. High lipid concentration (hyperlipidemia) in association with obesity, weight gain, hypertension and diabetes have been reported to be 
one of the major risk factors of cardiovascular disease, a leading cause of death ${ }^{4,5}$. Hyperlipidemia has been shown to be usually associated with elevated plasma level of low density lipoproteins (LDL), Triacylglycerol (TG), total cholesterol (TC), very low density lipoprotein (VLDL) and low level of plasma high density lipoprotein (HDL) ${ }^{3,6,7}$.

In ancient time past and until now, man's dependency on medicinal plants, in the practice of traditional medicine cannot be over emphasized. It was reported that in ancient time, people used medicinal plants' bark, leaves, root, fruits, and seeds taken mostly orally or applied on affected part to treat diseases and ailments. These include bone-setting, mental disorders, sickle-cell, anemia, epilepsy, liver and kidney problems, diabetes, stroke, malaria, and also as preservation and protection for the people ${ }^{8,9,10}$.

Chromolaena odorata (Linn) is a plant found in Nigeria and is said to be a native to South and Central America $^{11}$. The plant common name is siam weed, Botanical name is Chromolaena odorata (Linn), Local names in Nigeria include; Akintola in Yoruba, Awolowo in Igbo, Obiarakara in Hausa and Anagba-agwu in Idoma. It belongs to the family Asteraceae and is used as a medicinal herb in the South East of Nigeria. Findings by ${ }^{12}$ reveals the existence of about three hundred species of medicinal plants in use around the world in the pharmaceutical, food, cosmetics and perfumery industries. It was reported that in traditional medicine practice the plant is used as an anti-malaria remedy and can also be traditionally applied to wounds to stop bleeding ${ }^{12}$. It was reported that the aqueous extract and the decoction from the leaves of this plant have been used throughout Vietnam for the treatment of soft tissue wounds, burn wounds, and skin infections ${ }^{13}$. The anticancer activity of leaf extracts of Chromolaena odorata on human and mouse cell lines has been reported ${ }^{14,15}$ reported it popular antispasmodic, anti-protozoal, antifungal, antitrypanosomal, antibacterial and antihypertensive activities. Also, a previous study reported that reported that the plant possesses anti-inflammatory, astringent, diuretic and hepatotropic properties. A previous study reported that ethanolic and methanolic leaves extract of Chromolaena odorata have significant free radical scavenging action against nitric oxide and hydroxyl radical ${ }^{17}$. The present study is designed to investigate the hypoglycemic and hypolipidemic activities of fresh leaf extract of Chromolaena odorata (Linn) in albino wistar rats fed different concentrations of cholesterol enriched diet.

\section{MATERIALS AND METHODS Study Animals}

Albino Wister female rats weighing $100 \mathrm{~g}$ to $147 \mathrm{~g}$ were obtained from Department of Biochemistry, Faculty of Biological Sciences, University of Nigeria, Nsukka. Animals were housed in a well ventilated colony cages at an ambient temperature and relative humidity in the animal house of Department of Biochemistry, Faculty of Natural Sciences, Caritas University, Amorji - Nike, Enugu. The rats were allowed to acclimatize for one week prior to the experiment and had access to standardized palletized finisher feed and clean water within this period of acclimatization.

\section{Plant materials}

Fresh plant of siam weed were collected from behind Charity square of Caritas University Amorji - Nike, Enugu, Nigeria. The plant was identified and authenticated at the herbarium of the Department of Botany, Faculty of Biological Sciences, University of Nigeria, Nsukka. After which the leaves were collected, rid of dirt and squeezed in a clean container to release the liquid. Thereafter, the solution was filtered and the filtrate administered to the animals according to the required volume, based on body weight of the rats using the relationship below ${ }^{18}$. Plants leaves were always collected and extracted fresh when needed to be administered. This study adopted the use of fresh leaf extract in order to mimic the practice of the use of the fresh plant leaves by traditionalists and also to preserve some volatile bioactive components of the plant which may not withstand evaporation by extraction method.

$$
\text { Volume to beadministered }=\frac{\text { Weight of rats } x \text { Dose }}{\text { Concentration of the extract }}
$$

\section{Experimental Design}

The protocol for the study was in two phases. In the first phase, a total of 20 rats were grouped into four groups of five (5) rats each of test groups and control group. The rats in test groups were allowed free access to cholesterol enriched diet, pelletized finisher feed and water, while the normal control group was allowed free access pelletized finisher feed and water, all groups were fed for one week. The cholesterol enriched diet was made from the processed mixture of canned sardine, beef liver, hen's egg, Cray fish and margarine. These were fried without prior boiling (to prevent lose of nutrient) in the margarine (blue band butter), air dried, mixed and weighed. From the weighed mixture of the prepared cholesterol enriched diet was added to the pelletized finisher feed and the rats were fed.

Group I: normal control, fed only pelletized finisher feed (no cholesterol enriched diet).

Group II: fed pelletized finisher feed supplemented with $75 \mathrm{~g}$ of cholesterol enriched diet.

Group III: fed pelletized finisher feed supplemented with $108 \mathrm{~g}$ of cholesterol enriched diet.

Group IV: fed pelletized finisher feed supplemented with $148 \mathrm{~g}$ of cholesterol enriched diet.

In the second phase, the rats in groups II, III and IV were administered various dosages of fresh aqueous extracts of Chromolaena odorata (linn) leaves.

Group I: normal control, no administration.

Group II: administered $50 \mathrm{mg} / \mathrm{kg}$ body weight of extract.

Group III: administered $100 \mathrm{mg} / \mathrm{kg}$ body weight of extract.

Group IV: administered $150 \mathrm{mg} / \mathrm{kg}$ body weight of extract.

Collection of blood sample from the rats was done by capillary pressure insertion into side of the eye in an EDTA free tube, and serum collected stored at room temperature for immediate biochemical assays. 


\section{Estimation of parameters}

Blood glucose concentrations of rats were determined at cholesterol enriched diet fed state and after administration of fresh filtrate of Chromolaena odorata (linn) leaves. Glucose was assayed using glucose meter (Accu-check active blood Glucose monitoring system). Roche Diagnostics Mmbtt Sandhufer Strasse 116, 68305 Mannheim, Germany. Serial No: Gu 03802486. High density lipoprotein (HDL) was assayed using specific methods ${ }^{19,20}$, Low density lipoprotein (LDL) were determined using Belcher et al., method ${ }^{21}$, Total cholesterol (TC) was assayed by the enzymatic colorimetric cho-PAP method as described by Trinder et al., ${ }^{22}$, Triacyglycerol (TG) was assayed using the description by a previously used method ${ }^{23}$.

Statistical Analysis

Values obtained were analyzed statistically using one way Analysis of Variance (ANOVA) with a confidence level of $95 \% \quad(p<0.05)$, considered significant. A component of Graph Pad Instat3 Software version 3.05 by Graph Pad Inc. was used ${ }^{24}$. Results were expressed as mean \pm standard deviation.
RESULTS

The lipid profile of rats fed various concentrations (75, 108 and $148 \mathrm{~g}$ to group II, III and IV respectively) of cholesterol enriched diet is shown in Table 1. A significant $(P<0.05)$ increase was observed in TC, TG and LDL of test groups compared to control group. There was a significant $(P<0.05)$ decrease in HDL of the test groups compared to control group. Table 2 shows lipid profile of rats administered various dose of fresh leaf filtrate of Chromolaena odorata (linn) for four days. A significant $(P<0.05)$ increase was observed in HDL and significant $(P<0.05)$ decrease in LDL, TG and TC in group II, III and IV after administration compared to before administration of fed state of cholesterol enriched diet (Table1) in a non - dose dependent manner. Table 3 shows the blood glucose concentrations and effect of oral administration of the different doses $(50 \mathrm{mg} / \mathrm{kg}, 100 \mathrm{mg} / \mathrm{kg}$ and 150 $\mathrm{mg} / \mathrm{kg}$ body weight) on blood glucose concentrations of rats taken in fed state with cholesterol enriched diet and after administration of fresh leaf extract of Chromolaena odorata (linn).

Table 1: Lipid profile of rats fed cholesterol enriched diet of various concentrations $(75,108$ and $148 \mathrm{~g})$.

\begin{tabular}{lcccc}
\hline Groups & TC(mg/dl) & TG(mg/dl) & HDL(mg/dl) & LDL(mg/dl) \\
\hline GRPI & $102.00 \pm 16.10^{\mathrm{abc}}$ & $154.00 \pm 34.40^{\mathrm{abc}}$ & $69.00 \pm 60.50^{\mathrm{ab}}$ & $27.00 \pm 7.00^{\mathrm{abc}}$ \\
GRPII & $262.00 \pm 19.90^{\mathrm{a}}$ & $207.00 \pm 40.20^{\mathrm{a}}$ & $63.00 \pm 39.60$ & $157.00 \pm 58.60^{\mathrm{a}}$ \\
GRPIII & $272.00 \pm 79.20^{\mathrm{b}}$ & $163.00 \pm 42.41^{\mathrm{b}}$ & $24.00 \pm 22.60^{\mathrm{a}}$ & $215.00 \pm 65.10^{\mathrm{b}}$ \\
GRPIV & $233.00 \pm 36.30^{\mathrm{c}}$ & $232.00 \pm 41.00^{\mathrm{c}}$ & $40.00 \pm 19.70^{\mathrm{b}}$ & $146.00 \pm 33.50^{\mathrm{c}}$ \\
\hline
\end{tabular}

Results are mean \pm standard deviation, Values in the same column bearing similar superscripts are significantly different at $P<0.05$. (n=4). Key: GRP I: Control Group, GRP II: Test Group B, GRP III: Test group C, GRP IV: Test group D.

Table 2: Lipid profile of rats administered various dosage of fresh leaf aqueous extract of Chromolaena odorata (linn).

\begin{tabular}{lcccc}
\hline Groups & TC(mg/dl) & TG(mg/dl) & HDL(mg/dl) & LDL(mg/dl) \\
\hline GRPI & $151.00 \pm 46.70^{\mathrm{abc}}$ & $156.00 \pm 24.00^{\mathrm{ab}}$ & $132.00 \pm 19.70^{\mathrm{ab}}$ & $24.00 \pm 70.00^{\mathrm{abc}}$ \\
GRPII & $163.00 \pm 36.40^{\mathrm{a}}$ & $249.00 \pm 63.50^{\mathrm{a}}$ & $135.00 \pm 70.30$ & $35.00 \pm 22.10^{\mathrm{a}}$ \\
GRPIII & $191.00 \pm 39.80^{\mathrm{b}}$ & $142.00 \pm 48.10$ & $145.00 \pm 49.30^{\mathrm{a}}$ & $74.00 \pm 41.20^{\mathrm{b}}$ \\
GRPIV & $178.00 \pm 44.70^{\mathrm{c}}$ & $194.00 \pm 43.10^{\mathrm{b}}$ & $159.00 \pm 50.90^{\mathrm{b}}$ & $44.00 \pm 10.30^{\mathrm{c}}$ \\
\hline
\end{tabular}

Results are mean \pm standard deviation, Values in the same column bearing similar superscripts are significantly different at $P<0.05$. (n=4). Key: GRP I: Control Group, GRP II: Test Group B, GRP III: Test group C, GRP IV: Test group D.

After fresh leaf filtrate of Chromolaena odorata (linn) administration, the blood glucose levels of test groups (II, III and IV) decrease significantly $(P<0.05)$ compared to normal control (group I) and in fed state of cholesterol enriched diet in a non-dose dependent pattern, thus acerbating induced hypoglycemia.

Table 3: Blood glucose concentration $(\mathrm{mg} / \mathrm{dl})$ of rats in fed cholesterol enriched diet state and administered fresh leaf extract of Chromolaena odorata (linn) state.

\begin{tabular}{lcc}
\hline Groups & Fed state & Administered state \\
\hline GRPI & $102.75 \pm 32.75^{\mathrm{a}}$ & $60.32 \pm 57.21^{\mathrm{a}}$ \\
GRPII & $106.00 \pm 52.25^{\mathrm{b}}$ & $73.25 \pm 52.31^{\mathrm{b}}$ \\
GRPIII & $108.52 \pm 71.32^{\mathrm{c}}$ & $95.22 \pm 44.21^{\mathrm{c}}$ \\
GRPIV & $113.00 \pm 25.11^{\mathrm{d}}$ & $75.53 \pm 32.12^{\mathrm{d}}$ \\
\hline
\end{tabular}

Results are mean \pm standard deviation, Values in the same row bearing similar superscripts are significantly different at $P<0.05$. $(n=4)$. Key: GRP I: Control Group, GRP II: Test Group B, GRP III: Test group C, GRP IV: Test group D.

Table 4 shows the body weight of rats at fed state and after administration of fresh leaf extract of
Chromolaena odorata (linn). There was a significant $(P<0.05)$ decrease in weight of rats administered with varying doses of fresh leaf extract of Chromolaena odorata (linn) for four days compared to weight of fed cholesterol enriched diet state in dose dependent manner, thus exerting it anti obesity potential.

Table 4: Body weight (g) of rats fed cholesterol enriched diet and after administration of fresh leaf extract of Chromolaena odorata (linn).

\begin{tabular}{lcc}
\hline Groups & $\begin{array}{c}\text { Weight of fed } \\
\text { state }\end{array}$ & $\begin{array}{c}\text { After } \\
\text { administration }\end{array}$ \\
\hline GRPI & $170.06 \pm 26.80$ & $176.68 \pm 3.28$ \\
GRPII & $177.98 \pm 9.23^{\mathrm{a}}$ & $166.10 \pm 9.79^{\mathrm{a}}$ \\
GRPIII & $174.36 \pm 5.65^{\mathrm{b}}$ & $168.46 \pm 12.66^{\mathrm{b}}$ \\
GRPIV & $184.29 \pm 14.29^{\mathrm{c}}$ & $175.36 \pm 11.95^{\mathrm{c}}$ \\
\hline
\end{tabular}

Results are mean \pm standard deviation, Values in the same row bearing similar superscripts are significantly different at $P<0.05$. (n=6). Key: GRP I: Control Group, GRP II: Test Group B, GRP III: Test group C, GRP IV: Test group D

Results are mean \pm standard deviation, Values in the same row bearing similar superscripts are significantly different at $P<0.05$. (n=6). Key: GRP I: Control Group, 
GRP II: Test Group B, GRP III: Test group C, GRP IV: Test group D.

\section{DISCUSSION}

Feeding of the test groups rats in phase I with cholesterol enriched diet showed significant $(P<0.05)$ increase of low density lipoproteins (LDL), total cholesterol (TC) and triacylglycerol (TG) and decrease $(P<0.05)$ significantly of high density lipoproteins (HDL) (Table 1). The fed diet may have been the cause of the increase of LDL, TC and TG; and decrease of HDL in the animals. This finding is consistent with the previous report ${ }^{25}$ who showed that blood lipid profile of albino wistar rats changed when fed with cholesterol rich diet reported that the composition (combination of processed mixture of canned sardine, beef liver, hen's egg, Cray fish and margarine fried without prior boiling in the margarine can raise the level of lipid profile $^{6}$. This study also justify that such a formulation has rapid potential of raising LDL, TC, TG and body weight $^{6}$. The inverse levels between low density lipoproteins (LDL), known as Bad Cholesterol and high density lipoproteins (HDL), known as the good Cholesterol have been commonly reported. That is as LDL levels decrease, HDL levels will increase and vice versa and this study supports such grounds since HDL concentrations was lower than $\mathrm{LDL}^{26}$. Study also reported that high levels of HDL (above $60 \mathrm{mg} / \mathrm{dL}$ ) may be nearly as protective for the heart as low levels of LDL and HDL levels below $40 \mathrm{mg} / \mathrm{dL}$ are associated with an increased risk of cardiovascular disease ${ }^{26}$. Raised levels of serum total cholesterol and LDL have been reported to constitute risk factors in the development of cardiovascular diseases ${ }^{27}$. This risk could be due to deposition of their cholesteryl esters during their transport in the blood vessels which results in the hardening and narrowing of the vessels which causes cardiovascular diseases, especially atherosclerosis $^{28}$, Thus, the significant $(P<0.05)$ of LDL, TC and TG, and the significant $(P<0.05)$ decrease of HDL in this study may have negative influence in exacerbating cardiovascular diseases.

In phase II, the test animals were administered the fresh plant extract and showed significant $(P<0.05)$ increase in high density lipoprotein (HDL) and significant $(P<0.05)$ decrease in low density lipoprotein (LDL), total cholesterol (TC) and triacylglycerol (TG) (Table 2). These observations in the animals may have been caused by the administered fresh leaf extract of Chromolaena odorata (linn). Cholesterol is carried from other tissue of the body to the liver by a mediated action of high density lipoprotein (HDL) to be eliminated and low density lipoprotein (LDL) transport cholesterol to the tissues, increasing blood cholesterol. ${ }^{29}$ reported that the medicinal plant contains saponins. Thus, the cholesterol lowering effect may have been due to the phytochemical contents, since these phytochemicals have hypocholesterolemic properties. The reduction of fatty acids by the medicinal plant indicates it has the ability of lowering the lipid profile of the experimental animals. Siam weed appears to exert its hypolipidemic effect through the mechanism enabled by enhanced lecithin-cholesterol acyltrans-ferase (LCAT) activity (equation I). It has been reported that the enzyme LCAT and HDL are majorly involved in the transport and elimination of cholesterol from the body's tissues to the liver for elimination, hence it significant $(P<0.05)$ increase could be of benefit ${ }^{3}$. It has been reported that the phytochemicals saponins and phytosterols have ability of reducing plasma cholesterol and lipids concentration, thus may have contributed to the hypolipidemic activities of this medicinal plant with the reduction of the lipid profile except that HDL concentration increases. Phytosterols has inhibitory and competitive effect on dietary cholesterol uptake in the intestine and facilitate its excretion from the body, since they have related structure $^{30}$. Report by Nwokolo et al., ${ }^{31}$ on the nutrient content of Chromolaena odorata (linn) leaf showed that it contains some useful antioxidant mineral elements such as magnesium, manganese, iron, phosphorus, calcium, potassium, copper and zinc. It was reported that Zinc $(\mathrm{Zn})$ is a component of the enzyme superoxide dismutase, an antioxidant which protects and stops oxidation of LDL and fosters healthy transport of cholesterol ${ }^{3}$. Thus, the furnishing of zinc and copper by this medicinal plant could be responsible for the reduction in LDL, TG and TC. It appears the presence of copper and zinc in Siam weed as cofactors to the enzymes catalase and superoxide dismutase serve a complementary action. Superoxide dismutase converts superoxide $\left(\mathrm{O}^{2-}\right)$ product from LDL oxidation to hydrogen peroxide and oxygen $\left(\mathrm{H}_{2} \mathrm{O}_{2}\right.$ and $\left.\mathrm{O}_{2}\right)$ as the first line of defense to preserve cells from the damaging effects of superoxide. Catalase then metabolizes the hydrogen peroxide produced by superoxide dismutase to water and oxygen (equation II and III) ${ }^{32,17}$. The antioxidant role of manganese in superoxide dismutase in inflammation defense and protection against oxidative damage has been reported by Chang et al., ${ }^{33}$, which appears to support the observed inhibitory function in lipid peroxidation of Chromolaena odorata (linn) in this study. It could be that the medicinal plant inhibits the enzyme glycerol kinase, thereby reducing the production of triacylglycerol by preventing the mobilization of free fatty acid from the adipose tissue ${ }^{34}$.

Lecithin + Cholesterol $\stackrel{\text { LC.AT }}{\longrightarrow}$ Lysolecithin + Cholesterol esters

(I)

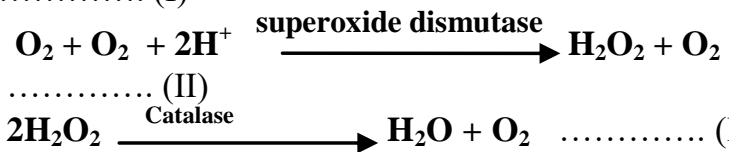

Thus, the ability to increase the serum concentration of HDL and reduce LDL, TG and TC could be due to the presence of these mineral elements, essential oils and phytochemicals.

The significant $(P<0.05)$ decrease in blood glucose level after administration of the leaf extract of Chromolaena odorata (linn) (Table 3 ) is supported by a previous study ${ }^{35}$. The reduction of blood glucose could be due to the presence of manganese ( $\mathrm{Mn}$ ) and magnesium $(\mathrm{Mg})^{31}$ and their function as cofactors to 
the enzymes glucokinase (Hexokinase), glucose 6phosphate and glycerol kinase. Magnesium ion $\left(\mathrm{Mg}^{2+}\right)$ is a cofactor required in glycolysis (breakdown) of glucose by hexokinase and phosphofructose kinase in the phosphorylation of glucose and fructose 6phosphate, to glucose 6-phosphate and fructose 1,6bisphosphate respectively ${ }^{3}$. Thus, the furnishing of $\mathrm{Mg}$ by siam weed seems to reduce blood glucose by the above mechanism.

The reduction in body weight of the test groups of the rats after administration of Chromolaena odorata (linn) fresh leaf extract (Table 4), is justified by Kewuchi et al., ${ }^{36}$ who reported a reduction of weight gain produced by the administration of the plant extract. The plant has been reported to be rich in phytochemicals such as flavonoids, terpenes and tannins; and essential oils ${ }^{16,37,38}$. The phytochemical contents of this plant could be responsible for the weight loss in the test animals in this study. The significantly low body weight produced by the medicinal plant, in the test animals may be a useful index in the management of obesity, hypertension, and reduction in blood pressure, improve and control coronary risk incidence, diabetes mellitus, hyperlipidemia, and physical functioning ${ }^{29}$.

\section{CONCLUSION}

It may be concluded that Chromolaena odorata (linn) fresh leaf aqueous extract possesses hypolipidemic and hypoglycemic ability, as seen in the effective reduction of low density lipoprotein, triacylglycerol and total cholesterol, raised concentrations of high density lipoproteins and reduction in blood glucose level. It therefore laid credence to the unscrupulous claim of the use of siam weed by traditionalist in the management of obesity and hypercholesterolemia.

\section{AUTHOR'S CONTRIBUTION}

The manuscript was carried out, written, and approved in collaboration with all authors.

\section{ACKNOWLEDGEMENTS}

The authors extend their thanks and appreciation to the Faculty of Natural Sciences Caritas University Amorji, Enugu, Nigeria to provide necessary facilities for this work.

\section{CONFLICT OF INTEREST}

No conflict of interest associated with this work

\section{REFERENCES}

1. Prentice, Andrew M. Overeating: the health risks. Obes Res 2001; 9:234S-238S https://doi.org/10.1038/oby.2001.124

2. Daniels SR, Greer FR; Committee on Nutrition. Lipid screening and cardiovascular health in childhood. Pediatrics 2008; 122(1):198-208. https://doi.org/10.1542/peds.2008-1349

3. Satyanarayana U, Chakrapa U. Biochemistry, in Metabolism of Lipids, $3^{\text {rd }}$ Ed., Kolkata 700009 (India), Arunabha Sen Books and Allied (P) Ltd., Chintamoni Das Lane 2010; 285-326: 410 - 420.

4. Franz MJ, Bantle JP, Beebe CA, Brunzell JD, Chiasson JL, Garg A, Holzeister LA, Hoogwerf B, Mayer-Davies
E, Mooradian AD, Purnell JQ, Wheeler M. Evidencebased nutrition principles and recommendations for the treatment and prevention of diabetes and related complications. Diabetes Care 2002; 25(1):148-198. https://doi.org/10.2337/diacare.25.1.202

5. Zicha J, Kunes J, Devynck MA. Abnormalities of Membrane function and lipid metabolism in hypertension: a review. American J Hypertension 1999; 12(3):315-331. https://doi.org/10.1016/S0895-7061(98)00178-2

6. Idoko A, Ikpe VPO, Nelson NO, Effiong JU, Alhassan AJ, Muhammad IU, Abubakar N, Abubakar SM. Effects of Lime Juice and Honey on Lipid Profile of Cholesterol Enriched Diet Fed Rat Model. Annual Res Rev Biol 2017; 20(3): 1-10. https://doi.org/10.9734/ARRB/2017/37213

7. Shen GX. Lipid disorders in diabetes mellitus and current management. Current Pharm Anal 2007; 3:17-24. https://doi.org/10.2174/157341207779802386

8. Farnsworth NR, Akerele O, Bingel AS, Soejarto DD, Guo Z. Medicinal plants in therapy. Bull. World Health Organization 1985; 63. PMID: 3879679

9. Sofowara A. Medicinal plants and traditional medicine in Africa. Spectrum Books Ltd, Ibadan, Nigeria. 1993; 191289. https://doi.org/10.4236/as.2018.91012

10. Gills LS. Ethno medical uses of Plants in Nigeria. University of Benin Press, Benin Nigeria 1992; 23-28. https://doi.org/10.5251/abjna.2016.7.5.220.247

11. Fosberg FR, Sachet MH. Flora of Micronesia, 4: Caprifoliaceae-Compositae. Smithsonian Institution Press, Washington. Smithsonian Contributions to Botany 1980; 46: 71. https://doi.org/10.5479/si.0081024X.46

12. Iwu MM. Handbook of African Medicinal Plants. Bocaraton, London CRC Press. 1993; 124-128.

13. Pala NA, Negi K, Todaria NP. Traditional uses of medicinal plants of Pauri Garhwal, Uttarakhand. Nature Sci 2010; 8:57-61.

14. Vital PG, Rivera LW. Antimicrobial activity and cytotoxicity of Chromolaena odorata (LF) King and robinson and Uncaria perrottetii (A. Rich) Merr extracts. J Medicinal Plants Res 2009; 3:511-518. https://doi.org/10.5897/JMPR

15. Phan TT, Wang L, P. See, R.J. Grayer, S.Y. Chan, and S.T. Lee. Phenolic Compounds of Chromolaena odorata Protect Cultured Skin Cells from Oxidative Damage: Implication for Cutaneous Wound Healing\|. Biological and Pharmacology Bulletin. 2001; 24(12):1373-1379. https://doi.org/10.1248/bpb.24.1373

16. Akinmoladun AC, Ibukun EC, Dan-Ologe IA. Phytochemical Constituents and Antioxidant Properties of Extracts from the Leaves of Chromolaena odorata L. Scientific Res Ess 2007; 2(6):191-194.

17. Bhargava D, Mondal CK, Shivapuri JN, Mondal S, Kar S. Antioxidant Properties of the Leaves of Chromolaena odorata Linn. J Institute of Medicine 2013; 35(1):53-56.

18. Muhammad IU, Alhassan AJ, Wudil AM, Jarumi IK. Toxicological and protective effect of aqueous stem bark extract of Khaya senegalensis (ASBEKS) on liver of experimental rat. British J App Sci Tech 2015; 9(6):600605.https://doi.org/10.9734/BJAST/2015/16545

19. Warnick GR, Nauck M, Rifai N. Evolution of methods for measurement of HDL cholesterol: from ultracentrifugation to homogeneous assays. Clin Chem 2001; 47:1579- 1596. https://doi.org/10.1093/clinchem/47.9.1579

20. Miller WG, Myers GL, Sakurabayashi I, Bachman LM, Caudill SP, Dziekonski A. Seven direct methods for measuring HDL and LDL cholesterol compared with ultracentrifugation reference measurement procedures. Clin Chem 2010; 56:977-986. https://doi.org/10.1373/clinchem.2009.142810

21. Belcher JD, McNamara JR, Grinstead GF, Rifai N, Warnick GR, Bachorik P. Measurement of low density lipoprotein cholesterol concentration. In: methods for clinical laboratory measurements of lipid and lipoprotein risk factors. Rifai N, Warnick GR (eds) AACC Press, Washington. 1991; 75-86. 
https://doi.org/10.4082/kifm.2015.36.4.168

22. Trinder P. Determination of blood glucose using an oxidase-peroxidase system with a non-carcinogenic chromogen. Ann Clin Biochem 1969; 22(2):158-61. http://dx.doi.org/10.1136/jcp.22.2.158

23. Bucola G, David H. Quantitative Determination of Serum Triglycerides by Use of Enzymes. Clinical Chem 1973; 19:476-482. PMID:4703655

24. Graph Pad Instat 3 Software; 2000. Available: www. graphpad.com

25. Onyeike EN, Monanu MO, Okoye CN. Changes in the blood lipid profile of wistar albino rats fed rich cholesterol diet, Annals of Biological Research 2012; 3 (11):51865191. https://doi.org/10.1016/S2221-1691(12)60234-2

26. Barter P, Gotto AM, LaRosa JC, Maroni J, Szarek M, Grundy SM, et al. HDL cholesterol, very low levels of LDL cholesterol, and cardiovascular events. N Engl J Med 2007; 357(13):1301-10. https://doi.org/10.1056/NEJMoa064278

27. Austin MA. Plasma Triglycerides and coronary heart disease. Arterioscler Thromb 1991; 11:2-14. https://doi.org/10.1161/01.atv.11.1.2

28. Brown MS, Goldstein JL. A receptor mediated pathway for cholesterol homeostasis. Sci 1986; 130:34-47. https://doi.org/10.1126/science.3513311

29. Soetan KO. Pharmacological and other beneficial effects of antinutritional factors in plants -a review. African $\mathrm{J}$ Biotech 2008; 7(25):4713-4721. https://doi.org/10.4314/ajb.v7i25.59660

30. Murrray IK, Mayer PA, Granner OK, Rodwel V. Cholesterol biosynthesis, Degradation and transport. In: Harper's Biochemistry. $2^{\text {nd }}$ Edn. Prentice Hall International Inc 1990; 240-254.

31. Nwokolo E. Leaf meals of cassava (manihot esculenta) and Siam weed (Eupatorium odoratum) as nutrient sources in poultry diets. Nutri. Report Int 1987; 36: 819826

32. Idoko A, Yalwa MG, Alhassan AJ, Rita O, Onubuiwe NN, Muhammad IU. Determination of lead and some parameters of oxidative stress in exhaust fume in relation to age in commercial tricyclists in Kano municipal. CARD Int J Medical Sci App Biosc 2017; 2(2): 11- 35.

33. Li C, Hai-Meng Z. The Role of Manganese Superoxide Dismutase in Inflammation Defense. Enzyme Research 2011; 6 https://doi.org/10.4061/2011/387176

34. Visner GA, Dougall WC, Wilson JM, Burr IA, Nick HS. Regulation of manganese superoxide dismutase by lipopolysaccharide, interleukin-1, and tumor necrosis factor. Role in the acute inflammatory response. J Biol Chem 1990, 265(5): 2856-2864. PMID: 2406241

35. Friday O Uhegbu, Chinedu Imo, Chibuzo H Onwuegbuchulam. Lipid lowering, hypoglycemic and antioxidant activities of Chromolaena odorata (L) and Ageratum conyzoides (L) ethanolic leaf extracts in albino rats. J Med Plants Stud 2016; 4(2): 155-159. https://doi.org/10.22270/ujpr.v3i1.R7

36. Kewuchi JC, Ikewuchi CC. Anti-cholesterolemic effect of aqueous extract of the leaves of Chromolaena odorata (L) King and Robinson (Asteraceae): Potential for the Reduction of Cardiovascular Risk. Pacific J Science Technol 2011; 12(2):385-391.

37. Asomugha AN Ezejiofor, Okafor PN, Ijeh II. Acute and cytotoxicity studies of aqueous and ethanolic leaf extracts of Chromolaena odorata. Pakistan J Biol Sci. 2015; 18:46-49. https://doi.org/10.3923/pjbs.2015.46.49

38. Prabhu V, Sujina I, Hemlal H, Ravi S. Essential oil composition, antimicrobial, MRSA and in-vitro cytotoxic activity of fresh leaves of Chromolaena odorata. J Pharm Res 2011; 4:4609-4611.

https://doi.org/10.3390/molecules24112130 